\title{
A Statement on Ethics from the HEART Group
}

Over the past several years, the editors of leading international cardiovascular journals have met to form the HEART group and to discuss areas of growing, common interest. Recently, the HEART group has developed a document that addresses general ethical principles in the conduct of the scientific process with which all of the editors concur. Published essentially simultaneously in all of the participating journals, including this journal, this document presents the ethical tenets accepted by all of the undersigned editors that will (continue to) guide their decisions in the editorial process.

These are the general principles on which the HEART Group is based and by which we, as a group, abide; however, please note that individual journal members and their respective societies may have their own rules and regulations that supersede the guidelines of the HEART Group.

\section{Acta Cardiologica}

Hugo Ector, MD, PhD

Editor-in-Chief

Patrizio Lancellotti, MD

Editor-in-Chief

American Journal of Cardiology

William C. Roberts, MD

Editor-in-Chief

American Journal of Geriatric Cardiology

Nanette K. Wenger, MD

Editor-in-Chief

\section{Annals of Noninvasive Electrocardiology}

Arthur J. Moss, MD

Editor-in-Chief

\section{Canadian Journal of Cardiology}

Eldon R. Smith, MD

Editor-in-Chief

\section{Cardiology}

Jeffrey S. Borer, MD

Editor-in-Chief

\author{
Cardiosource Review Journal \\ Kim A. Eagle, MD \\ Editor-in-Chief \\ Cardiovascular Drug Reviews \\ Jane Freedman, MD \\ Incoming Editor-in-Chief \\ Henry Krum, PhD \\ Incoming Editor-in-Chief \\ Chim Lang, MD \\ Incoming Editor-in-Chief
}

Cardiovascular Drugs and Therapy

Willem J. Remme, MD, PhD

Editor-in-Chief

\section{Cardiovascular Research}

Hans Michael Piper, MD, PhD

Editor-in-Chief

Catheterization and Cardiovascular Interventions

Christopher J. White, MD

Editor-in-Chief

\section{KARGER}

(C) 2008 S. Karger AG, Base

Fax +41613061234

E-Mail karger@karger.ch

www.karger.com 


\section{Circulation}

Joseph Loscalzo, MD, PhD

Editor-in-Chief

\section{Circulation Research}

Eduardo Marbán, MD, PhD

Editor-in-Chief

\section{Coronary Artery Disease}

Burton E. Sobel, MD Editor

\section{Current Opinion in Cardiology \\ Robert Roberts, MD Editor}

\section{Current Problems in Cardiology}

Shahbudin H. Rahimtoola, MD Editor

\section{Europace}

A. John Camm, MD Editor-in-Chief

\section{European Heart Journal \\ Frans Van de Werf, MD \\ Editor-in-Chief}

\author{
European Journal of Heart Failure \\ Karl Swedberg, MD, PhD \\ Editor-in-Chief \\ Heart \\ Adam D. Timmis, MD \\ Editor
}

Heart \& Lung: The Journal of Acute and Critical Care

Kathleen S. Stone, PhD, RN

Editor-in-Chief

\section{Heart Rhythm}

Douglas P. Zipes, MD Editor-in-Chief

\section{International Journal of Interventional Cardioangiology \\ David G. Iosseliani, MD Editor-in-Chief}

\section{Journal of Cardiovascular Computed Tomography}

Allen J. Taylor, MD

Editor-in-Chief

\section{Journal of Cardiovascular Pharmacology}

Michael R. Rosen, MD

Editor

\author{
Journal of Interventional Cardiology \\ Cindy L. Grines, MD \\ Editor-in-Chief
}

\author{
Journal of the American College of Cardiology \\ Anthony N. DeMaria, MD \\ Editor-in-Chief \\ JACC: Cardiovascular Imaging \\ Jagat Narula, MD, PhD \\ Editor-in-Chief
}

\section{JACC: Cardiovascular Interventions \\ Spencer B. King III, MD \\ Editor-in-Chief \\ Journal of Electrocardiology \\ Galen S. Wagner, MD \\ Editor-in-Chief}
Journal of Interventional Cardiac Electrophysiology
Sanjeev Saksena, MD Editor-in-Chief
Journal of the American Society of Echocardiography
Alan S. Pearlman, MD
Editor-in-Chief

\author{
Journal of Heart Valve Disease \\ Endre Bodnar, MD, PhD \\ Editor-in-Chief \\ Robert W. Emery, MD \\ Incoming Editor-in-Chief
}

\section{Journal of Thoracic and Cardiovascular Surgery}

Lawrence H. Cohn, MD

Editor-in-Chief

\section{Netherlands Heart Journal}

Ernst E. van der Wall, MD

Editor-in-Chief

\section{Pediatric Cardiology}

Ra-id Abdulla, MD

Editor-in-Chief

\section{Progress in Cardiovascular Diseases}

Michael Lesch, MD

Editor

\section{Scandinavian Cardiovascular Journal \\ Rolf Ekroth, MD \\ Chief Editor}

II 


\section{Ethics}

The purpose of this is to ensure transparency and honesty in the scientific process that promotes ethical conduct in the performance and publication of research.

The following will be considered as parts of this process:

(a) Disclosure of potential conflicts of interest for all involved in the performance of research and in the evaluation and publication process of a manuscript. Relevant relationships with commercial interests will be defined in terms of levels and nature of support. The nature of support will be listed as grants, supplies/equipment, type of employment, or personal income. Equity and royalty interests should be stated as well as any fiduciary relationship with the sponsor.

(b) Establish thorough review processes particularly alert to discovering scientific fraud and data falsification, redundant or duplicate publication, and plagiarism, and to adopt a uniform standard of dealing with authors guilty of fraudulent practices.

(c) Maintain confidentiality and embargos where appropriate.

(d) Create uniform criteria to establish authorship. To qualify for authorship, individuals must have made substantial contributions to the intellectual content of the paper in at least 1 of the following areas: conceived and designed the research; acquired the data; analyzed and interpreted the data; performed statistical analysis; handled funding and supervision; drafted the manuscript; or made critical revision of the manuscript for important intellectual content. Authors must give final approval of the version to be submitted and any revised version to be published. For multicenter trials, individuals who accept direct responsibility for the manuscript should fully meet the criteria for authorship previously defined; contributors not meeting these criteria should be acknowledged.

(e) Note avoidance of false claims of ownership and priority, by attention to previous publications.

(f) Establish avoidance of excessive claims of benefits of a product/technique in the publication as well as with news media.

(g) Note compliance with institutional review board requirements and, when appropriate, approved laboratory procedures for animal research, and that the research conforms to the ethical standards of the Declaration of Helsinki, the Geneva Declaration, the Belmont Report, and Good Clinical Practices from the FDA, and the submission conforms to the International Committee of Medical JournalEditors (ICMJE) 'Uniform Requirements for Manuscripts Submitted to Biomedical Journals: Writing and Editing for Biomedical Publication' (www. ICMJE.org).

With permission of the American College of Cardiology Foundation. 